\title{
Identification of ETS-1 target genes in human fibroblasts
}

\author{
JENS CLAUS HAHNE ${ }^{1}$, ALI FUAT OKUDUCU ${ }^{2}$, TANJA FUCHS ${ }^{3}$, \\ ALEXANDRA FLORIN $^{3}$ and NICOLAS WERNERT ${ }^{3}$
}

\author{
${ }^{1}$ Universitätsfrauenklinik Würzburg, D-97080 Würzburg; ${ }^{2}$ Institute of Pathology, Helios-Klinikum Emil von Behring, \\ D-14165 Berlin; ${ }^{3}$ Institute of Pathology, University of Bonn, P.O. Box 2120, D-53011 Bonn, Germany
}

Received October 27, 2010; Accepted December 22, 2010

DOI: 10.3892/ijo.2011.981

\begin{abstract}
The transcription factor Ets-1 plays several distinct critical roles in tumour development and progression by acting both in neoplastic cells and in the tumour stroma. Increased expression of Ets-1 in tumours is often associated with a worse prognosis. Stromal fibroblasts attribute an important part to the behaviour of malignant tumours. In this study we investigated the role of Ets-1 in the tumour stroma. It is well known that ets-1 expression in fibroblasts - one of the main components of the tumour stroma - can be induced by basic fibroblast growth factor (bFGF). We applied suppression subtractive hybridization ( $\mathrm{SSH}$ ) to identify genes that are differentially expressed between bFGF stimulated wild-type fibroblasts and fibroblasts with reduced Ets-1 expression. We selected clones up- or down-regulated in bFGF stimulated wild-type fibroblasts using SSH and functionally characterized them by reference to public databases using NCBI BLAST tools. Expression levels of genes corresponding to subtracted clones were analyzed using RT-PCR. Known genes were associated with diverse functions; novel Ets-1 regulated genes identified by SSH not only encoded components involved in matrix degradation (as cathepsin and PAI-2) but also constituents of the extracellular matrix (ECM) including $\alpha$-2-Type I collagen, TGF- $\beta$ induced protein, lumican and decorin. Our findings identify several potential novel target genes of Ets-1, and they provide potentially important insights into the role of Ets-1 in stromal fibroblasts for both remodelling and different functionalities of the ECM.
\end{abstract}

\section{Introduction}

Fibroblasts are important for synthesis of extracellular matrix (ECM) (1). ECM provides structure and elasticity for tissues, comparmentalized different cell types and serves as reservoir for growth factors by sequestering and protecting them in the microenvironment (2). Components of the ECM further

Correspondence to: Dr Nicolas Wernert, Institute of Pathology, University of Bonn, P.O. Box 2120, D-53011 Bonn, Germany

E-mail: nicolas.wernert@ukb.uni-bonn.de

Key words: Ets-1, fibroblasts, extracellular matrix, angiogenesis, suppression subtractive hybridization interact with specific adhesion receptors on cell surfaces and are involved in regulation of multiple cell functions, including adhesion, migration, proliferation and differentiation (3). ECM also plays a key role in many properties of cancers (4). During the onset of angiogenesis ECM is degraded by proteinases especially by matrix metalloproteinases (MMPs) $(5,6)$. ECM is part of the tumour stroma and serves, as angiogenesis proceedes, essential functions in supporting key signalling events involved in regulating migration, invasion, proliferation and survival (4,7-10).

The transcription factor Ets-1 is one of the critical mediators of ECM remodelling, but up to now Ets-1 is mainly associated with the regulation of MMPs and therefore connected to ECM degradation. The regulation of matrix degrading proteases by Ets-1 is well investigated especially in tumour invasion and metastasis (11-15). Since evolution has developed a restricted number of transcription factors for many gene regulatory networks it is probable that Ets-1 target genes are not restricted to those proteins involved in matrix-degradation in fibroblasts. The aim of the present work was therefore to identify further Ets-1 target genes in human fibroblasts and to enlighten the role and function of this transcription factor in the tumour stroma. For this purpose wild-type fibroblasts and fibroblasts with a reduced Ets-1 expression were stimulated with bFGF, a cytokine known to induce Ets-1 in fibroblasts and to be expressed by many tumour types $(11,14,16)$. Subtractive suppression hybridization ( $\mathrm{SSH}$ ) was performed with the stimulated cells to identify the differences in gene expression.

\section{Materials and methods}

Cell culture and stable transfections. Human foreskin fibroblasts (HFF) were cultured at $37^{\circ} \mathrm{C}$ in a humidified atmosphere containing $5 \% \mathrm{CO}_{2}$. They were maintained in Dulbecco's modified Eagle's medium supplemented with $10 \%$ heatinactivated fetal calf serum, $100 \mathrm{U} / \mathrm{ml}$ penicillin/streptomycin and $2 \mathrm{mM}$ L-glutamine. All reagents for cell culture were purchased from Invitrogen NV (Leek, The Netherlands).

The plasmid cDNA3-Ets-1-invers was transfected into the HFF cells by the calciumphosphate method, and $24 \mathrm{~h}$ after

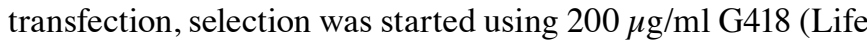
Technologies).

Western blot analysis. Cells were lysed by 5 freeze (on dry ice)thaw (room temperature) cycles. Lysates containing 15-20 $\mu \mathrm{g}$ 
Table I. Primers used for RT-PCR.

\begin{tabular}{|c|c|c|}
\hline Gene & Forward primer & Reverse primer \\
\hline$R P L-13 A$ & 5'-TACGCTGTGAAGGCATCAAC-3' & 5'-CACCATCCGCTTTTTCTTGT-3' \\
\hline$M M P 1$ & 5'-CTACACGGATACCCCAAGGA-3' & 5'-AACTTTGTGGCCAATTCCAG-3' \\
\hline$M M P 3$ & 5'-ACGAGGGCACGAGGAGCTAGC-3' & 5'-GGGTCAAATTCCAACTGAGAAG-3 \\
\hline$P A I-2$ & 5'-ATGGAGGATCTTTGTGTGG-3' & 5'-ATGGGGGTAACTGCATTGGC-3' \\
\hline Cathepsin & 5'-CAGGATGTGGGGGCTCAAGG-3' & 5'-GGGTGTCATTACTGCGGGAA-3' \\
\hline$\alpha$-2-Type I collagen & 5'-GTGGGAACTTTGCTGCTCAG-3' & 5'-AАCAАCTCCTCTCTCACCTG-3' \\
\hline TGF- $\beta$ induced protein & 5'-GCTGTCCAGCAGCCCTACCA-3' & 5'-GCTTTCAGCAGCCGGGCACA-3' \\
\hline Lumican & 5'-GGCCAGTACTATGATTATGA-3' & 5'-GCAGCTTCTTCAGTTGTTTCAA-3' \\
\hline Decorin & 5'-ATGAAGGCCACTATCATCCTC-3' & 5'-GAGAATTACTTATAGTTTCC-3' \\
\hline Gremlin & 5'-ACTCAGAGCAGACTCAGTCG-3' & 5'-CTGTTGCAGCCTTCCTCGTG-3' \\
\hline Retinoblastoma associated factor 600 & 5'-ACCCGAGCAACTTCCCGAGA-3' & 5'-CGGAATAGTCCTTCACTGCC-3' \\
\hline HSP-90 & 5'-ACTCTCACTATTGTGGATAC-3' & 5'-CATCATCGTTATGTTTGGTGA-3' \\
\hline TNF-receptor superfamily $11 B$ & 5'-ATTAAGTGGACCACCCAGGA-3' & 5'-GCTCCTATGTTTCAAGCAGA-3' \\
\hline AXL receptor tyrosine kinase & 5'-CTCACGGGCACCCTTCGGTG-3' & 5'-GTGACCTGGAGCCGTGGCCAG-3' \\
\hline MET receptor tyrosine kinase & 5'-CTGTGCTTGCACCTGGCATC-3' & 5'-CTGTTGACGCTGCCACAGCTA-3' \\
\hline$\beta$-2-adrenergic receptor & 5'-GGAAGCCATGCGCCGGACCA-3' & 5'-GGTGGGTGGCCCTGTACCAG-3' \\
\hline Stromal cell derived factor receptor 1 & 5'-TGGCCCTCTCGCTGTTGCTG-3' & 5'-GATGAAGAAGCGGCCAGAGG-3' \\
\hline $\begin{array}{l}\text { Insulin-like growth-factor binding } \\
\text { protein } 5\end{array}$ & 5'-CCTCTGTGGCCTCCATGGTA-3' & 5'-GTACTGTCCCACCTTGAGGG-3' \\
\hline Fli-1 & 5'-AGTGAGGGTCAACGTCAAGC-3' & 5'-ACACAGTTCCTTGCCATCCA-3' \\
\hline$M M T V-5 A$ & 5'-AGGTTGTAATTGAAGCCAATTC-3' & 5'-ATTCTTTGATGCCTGTCTTCGC-3' \\
\hline Rho-8/RAS GTPase & 5'-AAGGAGAGAAGAGCCAGCCAG-3' & 5'-CGGACATTGTCATAGTAAGG-3' \\
\hline ATP5G3 & 5'-TGATCCGAGCTGGATCCAGA-3' & 5'-GAATGCCAACATGTCAAGCA-3' \\
\hline 5-tubulin & 5'-TGCACATCCAGGCTGGTCAG-3' & 5'-AGCTCGGCGCCCTCTGTGTA-3' \\
\hline Serine/threonine-kinase 6 & 5'-CTGTTAAGGCTACAGCTCCA-3' & 5'-AGACAGGATGAGGTACACTG-3' \\
\hline Anilin, actin binding protein & 5'-CAGACAGTGATCTATCAAGC-3' & 5'-CTGATCCTTTGGATGGCATA-3' \\
\hline Thioredoxin & 5'-GTGAAGCAGATCGAGAGCAA-3' & 5'-GAAAACATGATTAGACTAATTC-3' \\
\hline
\end{tabular}

of total protein were analysed by $10 \%$ SDS-polyacrylamide gel (SDS-PAGE) electrophoresis and the proteins transferred onto nitrocellulose (Bio-Rad, München, Germany). After blocking with $5 \%$ non-fat dry milk in phosphate-buffered saline (PBS, Life Technologies, Darmstadt, Germany) for $2 \mathrm{~h}$ at room temperature, the filters were incubated in TBS-T (50 mM Tris, $150 \mathrm{mM} \mathrm{NaCl}, 0.1 \%$ Tween-20, $\mathrm{pH} 7.5$ ) and with anti-Ets-1 rabbit polyclonal serum (1:1000 dilution; Transduction Laboratories, Lexington, USA), then with a horseradish peroxidase-conjugated secondary antibody (1:5000; Amersham Biosciences, Freiburg, Germany). The antibodies were detected using the ECL reagents (Amersham Biosciences). The housekeeping protein $\beta$-actin was detected using a mouse monoclonal anti- $\beta$-actin antibody (1:5000; Sigma, Taufkirchen, Germany).

RNA isolation and c-DNA synthesis. Prior to RNA isolation cultures were stimulated with $10 \mathrm{ng}$ basic fibroblast growth factor (bFGF; Roche Diagnostics GmbH, Mannheim, Germany) per ml culture medium for $16 \mathrm{~h}$. Total cellular RNA was extracted from cell monolayers by the RNeasy kit (Qiagen, Hilden, Germany). The RNA quality was determined by Agilent
Bioanalyzer 2100 (Agilent Technologies, Böblingen, Germany) measurement. Only preparations with a RIN factor $\geq 9$ were used for further analysis.

Generation of cDNAs by reverse transcriptase was performed in $10 \mu \mathrm{l}$ reaction volume containing $2 \mu \mathrm{g}$ of total cellular RNA, $1 \mu \mathrm{l}$ of dNTPs $(10 \mathrm{mM}), 1 \mu \mathrm{l}$ of oligo(dT) $)_{12-18}$ primer $(10 \mathrm{mM})$, and RNAse-free water. After incubation at $65^{\circ} \mathrm{C}$ for $5 \mathrm{~min}$ the reaction mixture was placed on ice for $1 \mathrm{~min}$. Then $2 \mu \mathrm{l}$ of 10X RT buffer (Invitrogen, Karlsruhe, Germany), $4 \mu \mathrm{l} \mathrm{MgCl}_{2}$ (25 mM), $2 \mu \mathrm{l}$ of $0.1 \mathrm{M}$ DTT, and $1 \mu \mathrm{l} \mathrm{RNAseOUT}{ }^{\mathrm{TM}}$ recombinant RNAse inhibitor (Invitrogen) were added. After incubation at $42^{\circ} \mathrm{C}$ for $2 \min 1 \mu \mathrm{l}$ of Superscript II reverse transciptase $(50 \mathrm{U} / \mu 1$; Invitrogen) was added for reverse transcription at $42^{\circ} \mathrm{C}$ for $1 \mathrm{~h}$. Inactivation of the enzyme was performed by heating at $70^{\circ} \mathrm{C}$ for $15 \mathrm{~min}$. In a last step RNA was removed by addition of $1 \mu \mathrm{l} \mathrm{RNAseH}$ and incubation at $37^{\circ} \mathrm{C}$ for $20 \mathrm{~min}$.

Suppression subtractive hybridization (SSH). After stimulation with 10 ng bFGF (Roche Diagnostics $\mathrm{GmbH}$ ) per ml culture medium for $16 \mathrm{~h}$, SSH was performed between HFF and HFF-Ets-1-invers cells in both directions using the PCR-Select 
Table II. PCR conditions used for amplification with 25 cycles of denaturation, annealing and extension.

\begin{tabular}{|c|c|c|c|}
\hline & Denaturation & Annealing & Extension \\
\hline$r p L 13 A$ & $94^{\circ} \mathrm{C}$ for $30 \mathrm{sec}$ & $66^{\circ} \mathrm{C}$ for $30 \mathrm{sec}$ & $72^{\circ} \mathrm{C}$ for $30 \mathrm{sec}$ \\
\hline mтр 1 & $94^{\circ} \mathrm{C}$ for $30 \mathrm{sec}$ & $56^{\circ} \mathrm{C}$ for $30 \mathrm{sec}$ & $72^{\circ} \mathrm{C}$ for $30 \mathrm{sec}$ \\
\hline mmp 3 & $94^{\circ} \mathrm{C}$ for $30 \mathrm{sec}$ & $65^{\circ} \mathrm{C}$ for $30 \mathrm{sec}$ & $72^{\circ} \mathrm{C}$ for $30 \mathrm{sec}$ \\
\hline$P A I-2$ & $94^{\circ} \mathrm{C}$ for $30 \mathrm{sec}$ & $66^{\circ} \mathrm{C}$ for $30 \mathrm{sec}$ & $72^{\circ} \mathrm{C}$ for $30 \mathrm{sec}$ \\
\hline Cathepsin & $94^{\circ} \mathrm{C}$ for $30 \mathrm{sec}$ & $68^{\circ} \mathrm{C}$ for $30 \mathrm{sec}$ & $72^{\circ} \mathrm{C}$ for $30 \mathrm{sec}$ \\
\hline$\alpha$-2-Type I collagen & $94^{\circ} \mathrm{C}$ for $60 \mathrm{sec}$ & $67^{\circ} \mathrm{C}$ for $30 \mathrm{sec}$ & $72^{\circ} \mathrm{C}$ for $60 \mathrm{sec}$ \\
\hline TGF- $\beta$ induced protein & $94^{\circ} \mathrm{C}$ for $60 \mathrm{sec}$ & $72^{\circ} \mathrm{C}$ for $30 \mathrm{sec}$ & $72^{\circ} \mathrm{C}$ for $60 \mathrm{sec}$ \\
\hline Lumican & $94^{\circ} \mathrm{C}$ for $30 \mathrm{sec}$ & $55^{\circ} \mathrm{C}$ for $30 \mathrm{sec}$ & $72^{\circ} \mathrm{C}$ for $30 \mathrm{sec}$ \\
\hline Decorin & $94^{\circ} \mathrm{C}$ for $30 \mathrm{sec}$ & $53^{\circ} \mathrm{C}$ for $30 \mathrm{sec}$ & $72^{\circ} \mathrm{C}$ for $30 \mathrm{sec}$ \\
\hline Gremlin & $94^{\circ} \mathrm{C}$ for $60 \mathrm{sec}$ & $62^{\circ} \mathrm{C}$ for $30 \mathrm{sec}$ & $72^{\circ} \mathrm{C}$ for $60 \mathrm{sec}$ \\
\hline Retinoblastoma associated factor 600 & $94^{\circ} \mathrm{C}$ for $60 \mathrm{sec}$ & $63^{\circ} \mathrm{C}$ for $30 \mathrm{sec}$ & $72^{\circ} \mathrm{C}$ for $60 \mathrm{sec}$ \\
\hline$H S P-90$ & $94^{\circ} \mathrm{C}$ for $60 \mathrm{sec}$ & $53^{\circ} \mathrm{C}$ for $30 \mathrm{sec}$ & $72^{\circ} \mathrm{C}$ for $60 \mathrm{sec}$ \\
\hline TNF-receptor superfamily $11 B$ & $94^{\circ} \mathrm{C}$ for $60 \mathrm{sec}$ & $62^{\circ} \mathrm{C}$ for $30 \mathrm{sec}$ & $72^{\circ} \mathrm{C}$ for $60 \mathrm{sec}$ \\
\hline$A X L$ receptor tyrosine kinase & $94^{\circ} \mathrm{C}$ for $60 \mathrm{sec}$ & $72^{\circ} \mathrm{C}$ for $30 \mathrm{sec}$ & $72^{\circ} \mathrm{C}$ for $60 \mathrm{sec}$ \\
\hline MET receptor tyrosine kinase & $94^{\circ} \mathrm{C}$ for $60 \mathrm{sec}$ & $70^{\circ} \mathrm{C}$ for $30 \mathrm{sec}$ & $72^{\circ} \mathrm{C}$ for $60 \mathrm{sec}$ \\
\hline$\beta$-2-adrenergic receptor & $94^{\circ} \mathrm{C}$ for $60 \mathrm{sec}$ & $72^{\circ} \mathrm{C}$ for $30 \mathrm{sec}$ & $72^{\circ} \mathrm{C}$ for $60 \mathrm{sec}$ \\
\hline Stromal cell derived factor receptor 1 & $94^{\circ} \mathrm{C}$ for $60 \mathrm{sec}$ & $65^{\circ} \mathrm{C}$ for $30 \mathrm{sec}$ & $72^{\circ} \mathrm{C}$ for $60 \mathrm{sec}$ \\
\hline Insulin-like growth-factor binding protein 5 & $94^{\circ} \mathrm{C}$ for $60 \mathrm{sec}$ & $67^{\circ} \mathrm{C}$ for $30 \mathrm{sec}$ & $72^{\circ} \mathrm{C}$ for $60 \mathrm{sec}$ \\
\hline Fli-1 & $94^{\circ} \mathrm{C}$ for $60 \mathrm{sec}$ & $67^{\circ} \mathrm{C}$ for $30 \mathrm{sec}$ & $72^{\circ} \mathrm{C}$ for $60 \mathrm{sec}$ \\
\hline$M M T V-5 A$ & $94^{\circ} \mathrm{C}$ for $60 \mathrm{sec}$ & $63^{\circ} \mathrm{C}$ for $30 \mathrm{sec}$ & $72^{\circ} \mathrm{C}$ for $60 \mathrm{sec}$ \\
\hline Rho-8/RAS GTPase & $94^{\circ} \mathrm{C}$ for $60 \mathrm{sec}$ & $68^{\circ} \mathrm{C}$ for $30 \mathrm{sec}$ & $72^{\circ} \mathrm{C}$ for $60 \mathrm{sec}$ \\
\hline ATP5G3 & $94^{\circ} \mathrm{C}$ for $60 \mathrm{sec}$ & $66^{\circ} \mathrm{C}$ for $30 \mathrm{sec}$ & $72^{\circ} \mathrm{C}$ for $60 \mathrm{sec}$ \\
\hline 5-tubulin & $94^{\circ} \mathrm{C}$ for $60 \mathrm{sec}$ & $72^{\circ} \mathrm{C}$ for $30 \mathrm{sec}$ & $72^{\circ} \mathrm{C}$ for $60 \mathrm{sec}$ \\
\hline 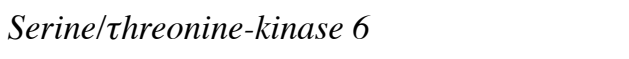 & $94^{\circ} \mathrm{C}$ for $60 \mathrm{sec}$ & $62^{\circ} \mathrm{C}$ for $30 \mathrm{sec}$ & $72^{\circ} \mathrm{C}$ for $60 \mathrm{sec}$ \\
\hline Anilin, actin binding protein & $94^{\circ} \mathrm{C}$ for $60 \mathrm{sec}$ & $58^{\circ} \mathrm{C}$ for $30 \mathrm{sec}$ & $72^{\circ} \mathrm{C}$ for $60 \mathrm{sec}$ \\
\hline Thioredoxin & $94^{\circ} \mathrm{C}$ for $60 \mathrm{sec}$ & $53^{\circ} \mathrm{C}$ for $30 \mathrm{sec}$ & $72^{\circ} \mathrm{C}$ for $60 \mathrm{sec}$ \\
\hline
\end{tabular}

cDNA Substraction Kit (Clontech, Heidelberg, Germany) according to the manufacturer's instructions. In brief, $2 \mu \mathrm{g}$ of mRNA from the tester and the driver was subjected to cDNA synthesis. Tester and driver cDNA were digested with RsaI. The tester cDNA was split into two groups, and each was ligated with different cDNA adapter. In a first hybridization reaction, an excess of driver was added to each sample of tester. The samples were heat-denaturated and allowed to anneal. Because of the second-order kinetics of hybridization, the concentration of high-and low-abundance sequences is equalized among the single-stranded tester molecules. At the same time, single-stranded tester molecules were significantly enriched for differentially expressed sequences. During a second hybridization, the two primary hybridization samples were mixed together without denaturation. Only the remaining equalized and substracted single-stranded tester cDNAs can reassociate forming double-stranded tester molecules with different ends. After filling in the ends with DNA polymerase, the entire population of molecules was subjected to nested PCR with two adapter-specific primer pairs. After that, secondary PCR products were used as templates for PCR amplification of the housekeeping gene GAPDH at 18, 23, 28 and 33 cycles to assure substraction efficiency.
Products of these amplified overhangs containing a substracted cDNA library $(6 \mu \mathrm{l})$ were ligated into a pcDNA vector (Invitrogen, Karlsruhe, Germany). Subsequently, the plasmid was transformed into E. coli strain DH5 $\alpha$. Bacteria were plated onto agar plates containing ampicillin $(100 \mu \mathrm{l} / \mathrm{ml})$ and incubated overnight at $37^{\circ} \mathrm{C}$. Single colonies were used for plasmid preparation (QIAprep ${ }^{\circledR}$ Spin Minprep Kit, Qiagen, Hilden, Germany). The cDNA inserts were identified by sequencing (Entelechon, Regensburg, Germany) and subsequent nucleic acid homology searches of the obtained sequences were performed using the BLAST server (http://www.ncbi. nlm.nih.gov/BLAST/).

PCR. For analysis of gene expression polymerase chain reaction (PCR) amplifications were performed using GeneAmp PCR System 9700 (Applied Biosystems, Foster City, USA). All primers were synthesised by TIB MolBiol (Berlin, Germany). The primer sequences used are given in Table I. PCR amplification of cDNA was performed in a reaction containing $2.5 \mu \mathrm{l}$ of $10 \mathrm{X}$ polymerase buffer, $1.5 \mathrm{mM} \mathrm{MgCl}_{2}, 0.2 \mathrm{mM}$ of each desoxynucleoside triphosphate, 25 pmol 5' primer and $3^{\prime}$ primer, $0.1 \mu \mathrm{l}(0.5 \mathrm{U}) \mathrm{Taq}$ DNA polymerase, $0.5 \mu \mathrm{l}$ cDNA template and sterile RNAse-free water added to a total volume 


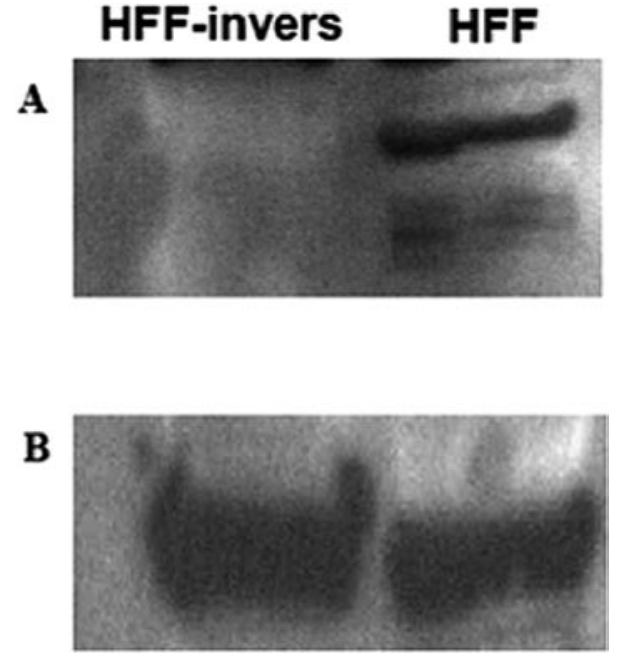

Figure 1. Analysis of Ets-1 expression. Cell extracts $(20 \mu \mathrm{g})$ were separated by SDS-PAGE and the proteins analysed by Western blotting using an antiEts-1 antibody (A). HFF cells show detectable amounts of Ets-1 and HFF-Ets-1-invers have decreased level of expression of the protein. Actin was used as internal standard (B).

of $25 \mu$ l. All PCR reagents were from Invitrogen (Karlsruhe, Germany).

We first amplified a housekeeping gene, encoding the constitutively expressed ribosomal protein L13A (rpL13A) in order to monitor RNA quality and cDNA synthesis and to ensure that equivalent amounts of cDNA were used in all PCR amplifications. All PCR reactions were preceded by a denaturation step at $94^{\circ} \mathrm{C}$ for 1 min followed by 25 cycles of denaturation, annealing and extension; PCR conditions for the different cDNAs are shown in Table II.

Each PCR reaction was finished by a final elongation step at $72^{\circ} \mathrm{C}$ for $10 \mathrm{~min}$. All PCR products were analysed by separation on a $2 \%$ agarose gel stained with ethidium bromide.

\section{Results}

A stable HFF cell line was established following transfection with an Ets-1-anti-sense expression vector. Ets-1-underexpressing (HFF-Ets-1-invers) cell line was selected from the pooled population of transfected cells, in order to avoid clonal variations. Ets-1 expression levels corresponded to the expected variations as shown by Western blotting with anti human Ets-1 antibody; while wild-type HFF cells expressed detectable amounts of Ets-1, the expression of the protein was not detectable in HFF-Ets-1-invers cells (Fig. 1A).

Subtractive suppression hybridization ( $\mathrm{SSH}$ ) has been demonstrated to be an effective method to identify new target genes in different systems $(17,18)$. Here we used the SSH approach for the identification of Ets-1 target genes in human fibroblasts. SSH was performed with bFGF stimulated wildtype HFF cells and HFF-Ets-1-invers cells in both directions. This substraction, described in Materials and methods, generated both a forward- and a reverse-substracted cDNA pool. Thus it was possible to identify genes that are activated as well as genes that are repressed by Ets-1.

Two hundred clones obtained from the cDNA library were analysed by sequencing and subsequent homology searches.

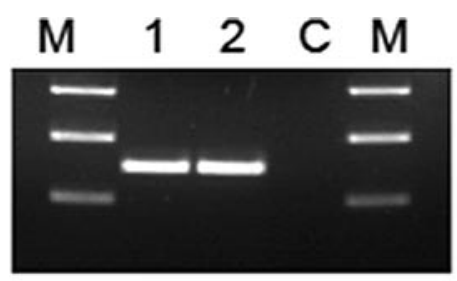

rpL13A

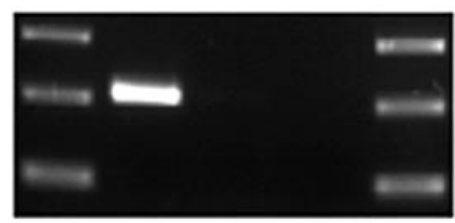

MMP 1

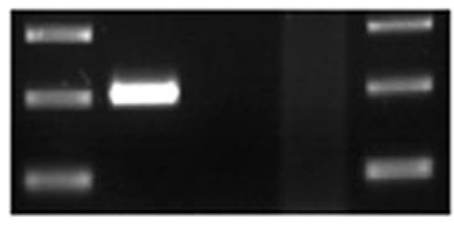

MMP 3

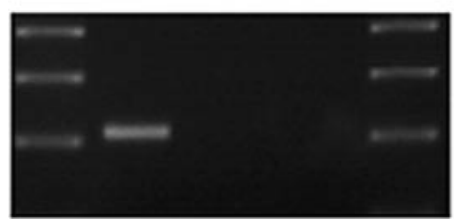

PAI-2

Figure 2. RT-PCR-analysis of known Ets-1 target genes in wild-typefibroblasts compared to fibroblasts with reduced ETS-1 expression. Expression of transcripts was analysed in $2 \%$ agarose gels in HFF wild-type (lane 1) and HFF cells with a reduced Ets-1 expression (HFF-Ets-1-invers; lane 2) after induction with bFGF $(10 \mathrm{ng} / \mathrm{ml})$ for $16 \mathrm{~h}$. The negative control (C) for any PCR is shown at the end of each line. Fragment sizes were evaluated with a PCR-marker (M); gene specific products are 251-bp for rpL13A, 280-bp for MMP 1, 280-bp for MMP 3 and 212-bp for PAI-2.

Differences in gene expression were verified by semiquantitative RT-PCR. As expected for a transcription factor a broad variety of genes involved in different cellular functions are regulated by Ets-1.

The capacity of the SSH method is demonstrated by identification of known Ets-1 target genes MMP-1, MMP-3 and PAI-2 in our experiments which were strongly expressed in wild-type HFF cells (Fig. 2). As further Ets-1 regulated genes in fibroblasts, genes coding for cathepsin, $\alpha$-2-Type I collagen, TGF- $\beta$ induced protein, lumican, decorin and gremlin were identified (Fig. 3). All these genes are involved in the build-up or the remodelling of the ECM. Transcripts of cathepsin, $\alpha$-2-Type I collagen, lumican, decorin and gremlin are expressed in wild-type HFF but not in HFF-invers cells. Therefore Ets-1 seems to be an essential activator for expression of these genes.

In contrast the gene coding for TGF- $\beta$ induced protein was expressed at a higher level in HFF-invers than in wild-type HFF cells. This gene is therefore probably repressed by Ets-1. Further genes that are regulated by Ets-1 in HFF cells are summarized in Fig. 4. For HSP-90, TNF-receptor-superfamily 11B (TNFRSF11B), insulin-like growth-factor binding protein 5 (Igfbp5), Fli-1 and MMTV-5A the transcription factor Ets-1 seems to be a potential activator. In contrast, Ets-1 seems to act as a repressor in HFF cells for retinoblastoma associated factor 600 (RBAF600), AXL-receptor-tyrosine kinase (AXL), 


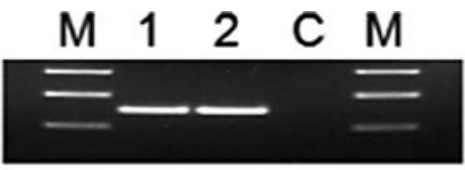

rpL13A

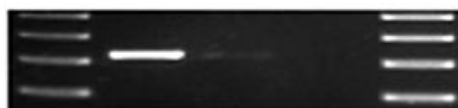

Cathepsin

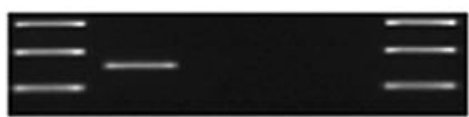

a-2-Type-1-Collagen

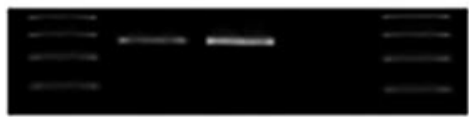

TGF- $\beta$-induced protein

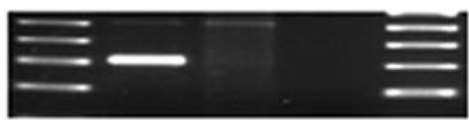

Lumican

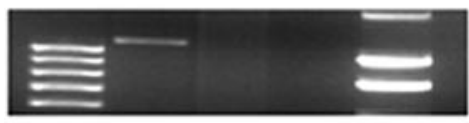

Decorin

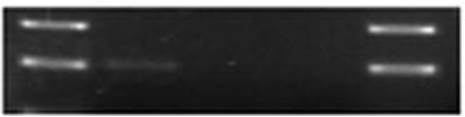

Gremlin

Figure 3. RT-PCR-analysis of Ets-1 target genes involved in building-up or remodelling of ECM. Expression of cathepsin, $\alpha$-2-type I collagen, TGF- $\beta$ induced protein, lumican, decorin and gremlin was assessed in HFF wild-type (lane 1) and HFF cells with a reduced Ets-1 expression (HFF-Ets-1-invers; lane 2) after induction with bFGF (10 ng/ml) for $16 \mathrm{~h}$. The negative control (C) for any PCR is shown at the end of every line. Gene specific products are 251-bp for rpL13A, 320-bp for cathepsin, 259-bp for $\alpha$-2-Type I collagen, 373-bp for TGF- $\beta$ induced protein, 313-bp for lumican, 1085-bp for decorin and 202-bp for gremlin, evaluated by PCR-marker (M).
MET-tyrosine kinase (MET), $\beta$-2-adrenergic receptor ( $\beta$-2AR), stromal cell derived factor receptor 1 (CXCR4), ATP5G3, 5-tubulin, serine-threonin-kinase 6 (STK6) and anilin/actin binding protein (Anilin).

\section{Discussion}

Since a limited number of transcription factors controls many gene regulatory networks it is probably that also Ets-1 target genes in fibroblasts are not restricted to those playing a role in matrix-degradation. In order to identify novel Ets-1 target genes we have analysed gene expression after bFGF stimulation of wild-type and Ets-1 repressed fibroblasts using SSH. In line with earlier studies we identified several known Ets-1 target genes involved in matrix remodelling (such as genes encoding MMP-1, MMP-3, PAI-2 and $\alpha$-2-Type I collagen) in these experiments $(11-14,19)$. In addition we could demonstrate several novel genes modulated by Ets-1 in human fibroblasts. As expected for a conserved transcription factor they comprise a broad variety of genes involved in different cellular functions. These genes encode cathepsin, TGF- $\beta$ induced protein, lumican, decorin, gremlin, HSP-90, TNF-receptor-superfamily 11B, insulin-like growth-factor binding protein 5, Fli-1, MMTV-5A, retinoblastoma associated factor 600 , AXL-receptor-tyrosine kinase, MET-tyrosine kinase, $\beta$-2-adrenergic receptor, stromal cell derived factor receptor 1, ATP5G3, 5-tubulin, serinethreonin-kinase 6 and anilin/actin binding protein.

The largest group among Ets-1 target genes in HFF identified in this investigation belongs to genes involved in the remodelling of the ECM. Genes encoding MMP-1, MMP-3, PAI-2 (SERPIN B2) and cathepsin all play a role in matrix
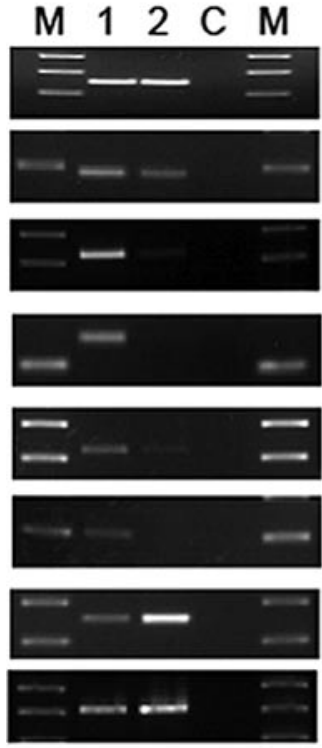

rpL13A

HSP-90

TNFRSF11B

Igfbp5

Fli-1

MMTV-5A

RBAF 600

$A X L$
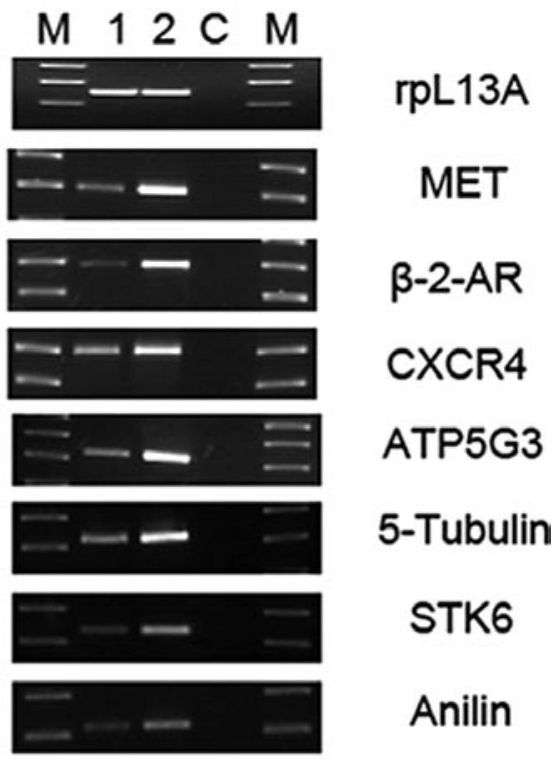

Figure 4. RT-PCR-analysis of further Ets-1 target genes identified by SSH. Expression of HSP-90, TNF-receptor-superfamily 11B (TNFRSF11B), insulin-like growth-factor binding protein 5 (Igfbp5), Fli-1, MMTV-5A, retinoblastoma associated factor 600 (RBAF600), AXL-receptor-tyrosine kinase (AXL), METtyrosine kinase (MET), $\beta$-2-adrenergic receptor ( $\beta$-2AR), stromal cell derived factor receptor 1 (CXCR4), ATP5G3, 5-tubulin, serine-threonin-kinase 6 (STK6) and anilin/actin binding protein (Anilin) was assessed in HFF wild-type (lane 1) and HFF cells with a reduced Ets-1 expression (HFF-Ets-1-invers; lane 2) after induction with bFGF (10 ng/ml) for $16 \mathrm{~h}$. The negative control (C) for any PCR is shown at the end of every line. Gene specific products are 251-bp for rpL13A, 211-bp for HSP-90, 324-bp for TNF-receptor superfamily 11B, 140-bp for insulin-like growth-factor binding protein 5, 322-bp for Fli-1, 198-bp for MMTV-5A, 256-bp for retinoblastoma associated factor 600, 411-bp for AXL receptor tyrosine kinase, 400-bp for MET receptor tyrosine kinase, 490-bp for $\beta$-2-adrenergic receptor, 497-bp for stromal cell derived factor receptor 1, 420-bp for ATP5G3, 322-bp for 5-tubulin, 231-bp for serine/threoninekinase 6 and 220-bp for anilin, evaluated by PCR-marker (M). 
Table III. The promoter regions of the different genes from public available sequences (National Center for Biotechnology Information or Ensembl Genome Browser) were used for searching potential Ets-1 binding sites with the PATCH 1.0 public program.

Number of potential Ets-1 binding sites in the promoter region
Described Ets-1 binding sites in the literature

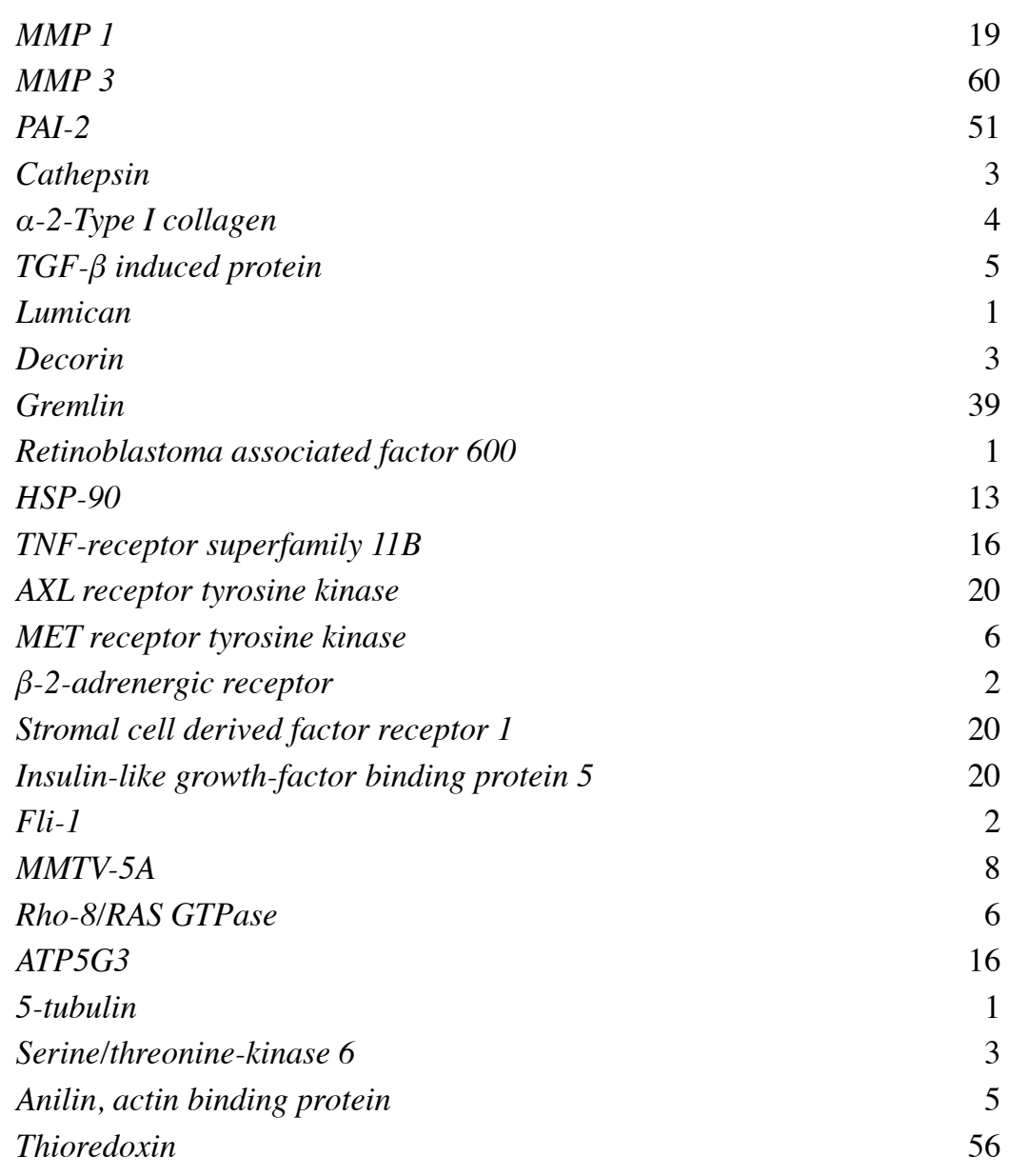

degradation (20-23). MET-tyrosine kinase and Fli-1 have already been described as Ets-1 target genes in human gastric cancer and in endothelial cells, respectively $(24,25)$. However, genes encoding the ECM components $\alpha$-2-Type I collagen, TGF- $\beta$ induced protein (BIGH3), lumican and decorin are also target genes of Ets-1.

The ECM is product of the resident cells (including fibroblasts) of each tissue and organ and serves both structural and functional roles (26). ECM exists in a state of dynamic equilibrium with its adjacent cell populations and is responsive to changing microenvironmental conditions and functional demands of the cells and their parental tissue or organ (27). The molecular composition of ECM is known to play a critical role for fundamental processes such as cellular migration and differentiation (3).

The transcription factor Ets-1 is considered one of the critical mediators of ECM remodelling by ECM degradation especially via regulation of MMPs (28-30). This issue has particularly been addressed in tumour angiogenesis, invasion and metastasis (11-15). ECM is degraded by proteinases, especially by MMPs during the onset of angiogenesis $(5,6)$.
ECM participates in the regulation of endothelial cell migration, invasion, proliferation and survival $(4,7,31)$. For HSP-90 the presence and function in the extracellular space has been described (32). There HSP-90 assists in activation of MMPs resulting in increased tumour invasiveness (32). It has also been shown by promoter deletion and mutational analysis that an Ets-1-like site in the promoter of the pai-2 gene is essential for bFGF induced pai-2 expression in endothelial cells (33).

Data of this study suggest a role of Ets-1 not only for degradation but also for build-up of ECM. According to our results Ets-1 plays a role not only in expression of MMP-1, MMP-3, PAI-2 and cathepsin but also in expression of lumican, decorin and $\alpha$-2-Type I collagen. It has recently been reported that Ets-1 stimulates $\alpha$-2-Type I collagen promoter activity in dermal fibroblasts fitting in well with our observations (19). Lumican and decorin, induced by Ets-1 according to our experiments, are both members of the leucine-rich proteoglycan family $(34,35)$. They both bind to collagen I and II and are able to fix and sequester growth factors (34-37). Besides modulation of growth factors and cytokine activities, proteoglycans are considered to regulate the water balance of 
the ECM, influence tissue biomechanics and facilitate cellular adhesion, proliferation as well as migration (38). It has been previously described that Ets-1 is also critical to bone and cartilage development (39) and we identified gremlin as another possible Ets-1 target gene in fibroblasts. This protein is known to be involved in bone development as a regulator of bone morphogenetic proteins. In addition gremlin has further roles in growth, differentiation and development (40). Gremlin has also been found to be over-expressed in human cancers (41). Recently it was shown that gremlin is produced by the stroma of human tumours and that it acts as proangiogenic factor (42). In the present study we did not demonstrate experimentally effects of Ets-1 upon the promoters of potential Ets-1 target genes we identified. However, bioinformatics promoter analysis reveals in all genes the presence of potential Ets-1 binding sites in the promoter regions (Table III) rendering possible direct effects of Ets-1 on expression of these genes. This has already been shown for MMP-1 and MMP-3 genes in previous studies $(11,43)$. Nevertheless indirect or combined effects of Ets-1 are likewise possible in view of our finding that Ets-1 induces in human fibroblasts other transcription factors such as the ETS family member Fli-1 or MMTV-5A.

In conclusion our results suggest that the expression level of Ets-1 within fibroblasts seems to be of pivotal importance for ECM composition. Ets-1 expression in fibroblasts may play many roles upon remodelling and different functional properties of ECM which is particularly interesting with respect to the importance attributed to stromal fibroblasts for behaviour of malignant tumours $(8,44-46)$. Ets-1 may function as activator or as repressor via association with specific cofactors and in combination with other transcription factors depending on promoter context (47). But until today a precise understanding of the role of Ets-1 in the complex network governing the expression of ECM proteins and the enzymes that degrade them is missing. Further work will be required to define the precise roles of Ets-1 for regulation of the genes identified in this study.

\section{Acknowledgements}

This work was supported by a grant from the German Research Association (DFG; grant no. WE 1104/8-1, 8-2 and 11-1) and German Cancer Aid (Deutsche Krebshilfe grant no. 107827).

\section{References}

1. Kalluri R and Zeisberg M: Fibroblasts in cancer. Nat Rev Cancer 6: 392-401, 2006.

2. Mosher DF, Sottile J, Wu C and McDonald JA: Assembly of extracellular matrix. Curr Opin Cell Biol 4: 810-818, 1992.

3. Huxley-Jones J, Robertson DL and Boot-Handford RP: On the origins of the extracellular matrix in vertebrates. Matrix Biol 12: 855-861, 2006

4. Lee JW and Juliano R: Mitogenic signal transduction by integrin- and growth factor receptor-mediated pathways. Mol Cells 17: 188-202, 2004.

5. Malemud CJ: Matrix metalloproteinases (MMPs) in health and disease: an overview. Front Biosci 11: 1696-1701, 2006.

6. Jodele S, Blavier L, Yoon JM and De Clerck YA: Modifying the soil to affect the seed: role of stromal-derived matrix metalloproteinases in cancer progression. Cancer Metastasis Rev 25 35-43, 2006.
7. Juliano RL: Signal transduction by cell adhesion receptors and the cytoskeleton: functions of integrins, cadherins, selectins, and immunoglobulin-superfamily members. Annu Rev Pharmacol Toxicol 42: 283-323, 2002.

8. Folkman J: Angiogenesis in cancer, vascular, rheumatoid and other disease. Nat Med 1: 27-31, 1995.

9. Bhowmick NA and Moses HL: Tumor-stroma interactions. Curr Opin Genet Dev 15: 97-101, 2005.

10. Micke P and Ostman A: Tumour-stroma interaction: cancerassociated fibroblasts as novel targets in anti-cancer therapy? Lung Cancer 45 (Suppl. 2): S163-S175, 2004.

11. Behrens P, Rothe M, Wellmann A, Krischler J and Wernert N: The Ets-1 transcription factor is up-regulated together with MMP 1 and MMP 9 in the stroma of pre-invasive breast cancer. J Pathol 194: 43-50, 2001.

12. Hahne JC, Okuducu AF, Kaminski A, Florin A, Soncin F and Wernert N: Ets-1 expression promotes epithelial cell transformation by inducing migration, invasion and anchorage-independent growth. Oncogene 24: 5384-5388, 2005.

13. Rothhammer T, Hahne JC, Florin A, Poser I, Soncin F, Wernert N and Bosserhoff AK: The Ets-1 transcription factor is involved in the development and invasion of malignant melanoma. Cell Mol Life Sci 61: 118-128, 2004.

14. Wernert N, Gilles F, Fafeur V, Bouali F, Raes MB, Pyke C, Dupressoir T, Seitz G, Vandenbunder B and Stehelin D: Stromal expression of c-Ets1 transcription factor correlates with tumor invasion. Cancer Res 54: 5683-5688, 1994.

15. Hahne JC, Okuducu AF, Sahin A, Fafeur V, Kiriakidis S and Wernert N: The transcription factor ETS-1: its role in tumour development and strategies for its inhibition. Mini Rev Med Chem 8: 1095-1105, 2008.

16. Davidson B, Goldberg I, Gotlieb WH, Kopolovic J, Risberg B, Ben-Baruch G and Reich R: Coordinated expression of integrin subunits, matrix metalloproteinases (MMP), angiogenic genes and Ets transcription factors in advanced-stage ovarian carcinoma: a possible activation pathway? Cancer Metastasis Rev 22: 103-115, 2003.

17. Rebrikov D, Desai S, Kogan YN, Thornton AM and Diatchenko L: Subtractive cloning: new genes for studying inflammatory disorders. Ann Periodontol 7: 17-28, 2002.

18. Rebrikov DV, Desai SM, Siebert PD and Lukyanov SA: Suppression subtractive hybridization. Methods Mol Biol 258: 107-134, 2004.

19. Czuwara-Ladykowska J, Shirasaki F, Jackers P, Watson DK and Trojanowska M: Fli-1 inhibits collagen type I production in dermal fibroblasts via an Sp1-dependent pathway. J Biol Chem 276: 20839-20848, 2001.

20. Affara NI, Andreu P and Coussens LM: Delineating protease functions during cancer development. Methods Mol Biol 539: 1-32, 2009.

21. Arakaki PA, Marques MR and Santos MC: MMP-1 polymorphism and its relationship to pathological processes. J Biosci 34: 313-320, 2009.

22. Croucher DR, Saunders DN, Lobov S and Ranson M: Revisiting the biological roles of PAI2 (SERPINB2) in cancer. Nat Rev Cancer 8: 535-545, 2008.

23. Verma RP and Hansch C: Matrix metalloproteinases (MMPs): chemical-biological functions and (Q)SARs. Bioorg Med Chem 15: 2223-2268, 2007.

24. Kitamura S, Miyazaki Y, Hiraoka S, Toyota M, Nagasawa Y, Kondo S, Kiyohara T, Shinomura Y and Matsuzawa Y: PPARgamma inhibits the expression of c-MET in human gastric cancer cells through the suppression of Ets. Biochem Biophys Res Commun 265: 453-456, 1999.

25. Lelievre E, Lionneton F, Mattot V, Spruyt N and Soncin F: Ets-1 regulates fli-1 expression in endothelial cells. Identification of ETS binding sites in the fli-1 gene promoter. J Biol Chem 277: 25143-25151, 2002.

26. Nelson CM and Tien J: Microstructured extracellular matrices in tissue engineering and development. Curr Opin Biotechnol 17: 518-523, 2006.

27. Bissell DM, Stamatoglou SC, Nermut MV and Hughes RC: Interactions of rat hepatocytes with type IV collagen, fibronectin and laminin matrices. Distinct matrix-controlled modes of attachment and spreading. Eur J Cell Biol 40: 72-78, 1986.

28. Westermarck $\mathbf{J}$ and Kahari VM: Regulation of matrix metalloproteinase expression in tumor invasion. FASEB J 13: 781-792, 1999. 
29. Okuducu AF, Zils U, Michaelis SA, Michaelides S and von Deimling A: Ets-1 is up-regulated together with its target gene products matrix metalloproteinase-2 and matrix metalloproteinase-9 in atypical and anaplastic meningiomas. Histopathology 48: 836-845, 2006.

30. Davidson B, Reich R, Risberg B and Nesland JM: The biological role and regulation of matrix metalloproteinases (MMP) in cancer. Arkh Patol 64: 47-53, 2002

31. Hynes RO, Lively JC, McCarty JH, Taverna D, Francis SE, Hodivala-Dilke $\mathrm{K}$ and Xiao Q: The diverse roles of integrins and their ligands in angiogenesis. Cold Spring Harb Symp Quant Biol 67: 143-153, 2002 .

32. Eustace BK and Jay DG: Extracellular roles for the molecular chaperone, hsp90. Cell Cycle 3: 1098-1100, 2004.

33. Kaneko T, Fujii S, Matsumoto A, Goto D, Ishimori N, Watano K, Furumoto T, Sugawara T, Sobel BE and Kitabatake A: Induction of plasminogen activator inhibitor-1 in endothelial cells by basic fibroblast growth factor and its modulation by fibric acid. Arterioscler Thromb Vasc Biol 22: 855-860, 2002.

34. Grover J, Liu CY, Kao WW and Roughley PJ: Analysis of the human lumican gene promoter. J Biol Chem 275: 40967-40973, 2000.

35. Santra M, Danielson KG and Iozzo RV: Structural and functional characterization of the human decorin gene promoter. A homopurine-homopyrimidine $\mathrm{S} 1$ nuclease-sensitive region is involved in transcriptional control. J Biol Chem 269: 579-587, 1994.

36. Ruoslahti E and Yamaguchi Y: Proteoglycans as modulators of growth factor activities. Cell 64: 867-869, 1991.

37. Kresse $\mathrm{H}$ and Schonherr E: Proteoglycans of the extracellular matrix and growth control. J Cell Physiol 189: 266-274, 2001.

38. Naito Z: Role of the small leucine-rich proteoglycan (SLRP) family in pathological lesions and cancer cell growth. J Nippon Med Sch 72: 137-145, 2005

39. Kawahata H, Kikkawa T, Higashibata Y, Sakuma T, Huening M, Sato M, Sugimoto M, Kuriyama K, Terai K, Kitamura Y and Nomura S: Enhanced expression of Runx2/PEBP2alphaA/ CBFA1/AML3 during fracture healing. J Orthop Sci 8: 102-108, 2003.
40. Schmitt JM, Hwang K, Winn SR and Hollinger JO: Bone morphogenetic proteins: an update on basic biology and clinical relevance. J Orthop Res 17: 269-278, 1999.

41. Namkoong H, Shin SM, Kim HK, Ha SA, Cho GW, Hur SY, Kim TE and Kim JW: The bone morphogenetic protein antagonist gremlin 1 is overexpressed in human cancers and interacts with YWHAH protein. BMC Cancer 6: 74, 2006.

42. Stabile $\mathrm{H}$, Mitola $\mathrm{S}$, Moroni $\mathrm{E}$, et al: Bone morphogenic protein antagonist Drm/gremlin is a novel proangiogenic factor. Blood 109: 1834-1840, 2007.

43. Baillat D, Begue A, Stehelin D and Aumercier M: ETS-1 transcription factor binds cooperatively to the palindromic head to head ETS-binding sites of the stromelysin-1 promoter by counteracting autoinhibition. J Biol Chem 277: 29386-29398, 2002.

44. Kaminski A, Hahne JC, el Haddouti M, Florin A, Wellmann A and Wernert N: Tumour-stroma interactions between metastatic prostate cancer cells and fibroblasts. Int J Mol Med 18: 941-950, 2006.

45. Basset P, Bellocq JP, Wolf C, Stoll I, Hutin P, Limacher JM, Podhajcer OL, Chenard MP, Rio MC and Chambon P: A novel metalloproteinase gene specifically expressed in stromal cells of breast carcinomas. Nature 348: 699-704, 1990.

46. Crawford HC and Matrisian LM: Tumor and stromal expression of matrix metalloproteinases and their role in tumor progression. Invasion Metastasis 14: 234-245, 1994.

47. Sharrocks AD: The ETS-domain transcription factor family. Nat Rev Mol Cell Biol 2: 827-837, 2001.

48. Mizui M, Isaka Y, Takabatake Y, Sato Y, Kawachi H, Shimizu F, Takahara S, Ito T and Imai E: Transcription factor Ets-1 is essential for mesangial matrix remodeling. Kidney Int 70: 298-305, 2006.

49. Nishikawa A, Iwasaki M, Akutagawa N, Manase K, Yamashita S, Endo T and Kudo R: Expression of various matrix proteases and Ets family transcriptional factors in ovarian cancer cell lines: correlation to invasive potential. Gynecol Oncol 79: 256-263, 2000 . 